\title{
PENGARUH SEMANGAT KERJA DAN KEDISIPLINAN TERHADAP KINERJA PEGAWAI PADA DINAS PERPUSTAKAAN KABUPATEN INDRAGIRI HULU
}

\author{
Kusmana \\ STAI Nurulfalah Airmolek \\ E-mail: kusmanagibran08@gmail.com
}

\begin{abstract}
Penelitian ini dilaksanakan pada Kantor Dinas Perpustakaan Kabupaten Indragiri Hulu yang berlokasi di Jalan Bupati Tulus Rengat. Penelitian ini bertujuan untuk mengetahui Pengaruh semangat kerja dan kedisiplinan kerja terhadap kinerja pegawai pada Dinas Perpustakaan Kabupaten Indragiri Hulu. Dalam melakukan penelitian ini penulis menggunakan metode interview dan quesioner dalam upaya pengumpulan data. Penulis memerlukan data-data yang berkaitan dengan masalah yang diteliti. Adapun jenis dan sumber data yang dipergunakan dalam penelitian ini adalah data primer dan skunder. Adapun yang menjadi populasi dan sampel dalam penelitian ini adalah seluruh jumlah pegawai yang bekerja pada Dinas Perpustakaan Kabupaten Indragiri Hulu. Untuk hasil Koefisien Korelasi antara Semangat Kerja dan Kedisiplinan terhadap kinerja adalah sebesar 0.915 berarti mendekati 1, maka disini dapat dikatakan bahwa semangat kerja dan kedisiplinan terhadap kinerja terdapat hubungan yang sangat kuat atau positif. Sedangkan berdasarkan tabel analisis di atas diperoleh angka $R^{2}$ ( $R$ Square) atau disebut koefisien determinasi adalah sebesar 0.813. artinya 81.3\%. menunjukkan persentase sumbangan variabel independen (semangat kerja dan kedisiplinan) terhadap variabel dependen (kinerja) Atau variasi variabel independen yang digunakan dalam model (semangat kerja dan kedisiplinan) mampu menjelaskan sebesar $81.3 \%$ dari variasi variabel dependen (kinerja). Sedangkan sisanya sebesar $18.7 \%$ dipengaruhi oleh variabel lain yang tidak diteliti dalam penelitian ini
\end{abstract}

Keywords: Kinerja, Semangat kerja dan Kedisiplinan

\section{A. PENDAHULUAN}

Sudah kita ketahui bersama bahwa pegawai atau sumber daya manusia ( SDM ) memiliki peranan sentral dalam mengembangkan dan mencapai sasaran- sasaran organisasi. Akan tetapi, keberadaan SDM yang hebat dan unggul malah bisa jadi boomerang bagi organisasi jika tidak disertai perencanaan dan pengendalian SDM itu sendiri. Di sisi lain harmoni dalam tata hubungan antar manusia baik antar sesama anggota organisasi maupun hubungan atasan bawahan juga menjadi hal penting untuk dimiliki oleh organisasi manapun terlebih lagi pada organisasi yang secara langsung dan insentifnya diterjemahlkan langsung kedalam bentuk uang.

Organisasi bisa berdiri diawali adanya beberapa tujuan tertentu yang hanya dapat dicapai melalui tindakan yang harus dilakukan dengan persetujuan bersama. Jadi apabila tujuan itu membawa kebaikan bagi anggota maupun masyarakat, namun ciri organisasi itu sama. Bahwa perilaku organisasi terarah pada tujuan ( Directed behavior). Artinya organisasi itu mengejar tujuan dan sasaran yang dapat dicapai secara lebih efisien dan lebih efektif dengan tindakan yang dilakukan secara bersama-sama.

Semangat kerja merupakan perwujudan dari moral yang tinggi,bahkan ada yang mengidentifikasikan atau menterjemahkan secara bebas bahwa moral kerja yang tinggi adalah semangat kerja. Dengan semangat kerja yang tinggi, maka kinerja akan meningkat karena para karyawan akan melakukan pekerjaan secara lebih giat sehingga pekerjaan dapat diharapkan lebih cepat dan lebih baik. Begitu juga sebaliknya jika semangat kerja turun maka kinerja akan turun juga. Jadi dengan kata lain semangat kerja akan berpengaruh terhadap kinerja pegawai .Instansi harus memiliki kinerja yang baik/tinggi dapat membantu instansi memperoleh keuntungan sebaliknya, bila kinerja turun dapat merugikan instansi. Oleh karenanya kinerja pegawai perlu memperoleh antara lain dengan jalan melaksanakan kajian berkaitan dengan variabel semangat kerja dan kedisiplinan.

Tabel 1 Rekap Absen Per Tahun 2016 - 2018

Pada Dinas Perpustakaan Kabupaten Indragiri Hulu

\begin{tabular}{|c|c|c|c|c|c|c|c|c|}
\hline \multirow{2}{*}{ Periode } & \multirow{2}{*}{$\begin{array}{c}\text { Jumlah } \\
\text { PNS }\end{array}$} & \multirow{2}{*}{$\begin{array}{l}\text { Jumlah } \\
\text { Honorer }\end{array}$} & \multirow[t]{2}{*}{ Jumlah } & \multicolumn{3}{|c|}{ Keterangan } & \multirow{2}{*}{$\begin{array}{c}\text { Total Hari } \\
\text { Kerja }\end{array}$} & \multirow{2}{*}{$\begin{array}{l}\text { \% Tingkat } \\
\text { Absensi }\end{array}$} \\
\hline & & & & Sakit & Izin & Alpha & & \\
\hline 2016 & 27 & 34 & 61 & 4 & 109 & 6 & 249 & 14,1 \\
\hline 2017 & 25 & 36 & 61 & 5 & 114 & 4 & 251 & 8 \\
\hline 2018 & 28 & 57 & 85 & 45 & 119 & 4 & 247 & 68,0 \\
\hline
\end{tabular}

Sumber : Dinas Perpustakaan kabupaten Indragiri hulu

Dari tabel diatas dapat dilihat bahwa kedisiplinan pegawai dinas perpustakaan kabupaten Indragiri hulu kurang baik dilihat dari tingkat absensi yang cukup tinggi. Dari tabel tersebut menunjukan bahwa pegawai dinas perpustakaan kabupaten Indragiri hulu tiap tahunnya ada yang tidak hadir 
dengan tiga indikator yaitu sakit,izin,alpha yang cenderung mengalami peningkatan tiap tahunnya.

Disiplin merupakan sikap mental yang tecermin dalam perbuatan tingkah laku perorangan, kelompok atau masyarakat berupa kepatuhan atau ketaatan terhadap peraturan, ketentuan, etika, norma dan kaidah yang berlaku. Disiplin kerja adalah sikap kejiwaan seseorang atau kelompok yang senantiasa berkehendak untuk mengikuti atau mematuhi segala peraturan yang telah ditentukan. Kedisiplinan dapat dilakukan dengan latihan antara lain dengan bekerja menghargai waktu dan biaya akan memberikan pengaruh yang positif terhadap produktivitas kerja pegawai.

\section{Tabel 2 Budaya pelayanan dan Tata tertib kedisiplinan pada Dinas Perpustakaan Kabupaten Indragiri Hulu.}

\begin{tabular}{|l|l|l|}
\hline No & $\begin{array}{l}\text { Indikato } \\
\text { r }\end{array}$ & \multicolumn{1}{c|}{ Budaya pelayanan } \\
\hline 1. & Pegawai & $\begin{array}{l}\text { a. Senyum,sapa,salam,senang,sopan,sabar. } \\
\text { b. Tamu wajib berpakaian sopan dan rapi. } \\
\text { c. Tamu wajib mengisi buku tamu yang disediakan. } \\
\text { d. Tamu wajib konfirmasi tentang keperluan kepada petugas jaga. } \\
\text { e. Silahkan menunggu di ruang tamu yang telah disediakan. } \\
\text { f. Membuang sampah di tempat sampah yang telah disediakan. } \\
\text { g. Bertutur sapa yang sopan dan baik. }\end{array}$ \\
\hline 2. & $\begin{array}{l}\text { Pengunj } \\
\text { ung }\end{array}$ & $\begin{array}{l}\text { a. Tidak makan,minum dan merokok selama berada dalam ruang } \\
\text { perpustakaan. } \\
\text { b. Tidak membuat keributan dan tindakan lain yang dapat mengganggu } \\
\text { sesama pengunjung. } \\
\text { c. Tidak mencoret-coret meja dan peralatan lain dalam ruang perpustakaan. }\end{array}$ \\
\hline
\end{tabular}

Sumber : Dinas Perpustakaan kabupaten Indragiri hulu

Sebagai pegawai kita wajib menerapkan budaya pelayanan dan tata tertib kedisiplinan pada dinas perpustakaan. Agar terciptanya suatu organisasi yang baik terhadap sesama pekerja. Untuk itu kita pegawai wajib menerapkan senyum, sapa, salam, senang, sopan, dan sabar untuk menciptakan suatu hal yang baik terhadap pemustaka yang berkunjung pada dinas perpustakaan.

Kinerja pegawai tidak di pengaruhi oleh semangat kerja pegawai saja tetapi juga bisa dilihat dari bagaimana cara kerjanya dan absensinya.Jika seorang pegawai mempunyai semangat kerja yang tinggi maka pasti akan mendapatkan apresiasi yg tinggi dari instansinya tersebut.

\section{Kinerja Pegawai}

Pengertian kinerja merupakan suatu hasil kerja yang dihasilkan oleh seorang

Eko dan Bisnis (Riau Economics and Business Reviewe) Volume 10, Nomor 3, 27 September 2019 pegawai diartikan untuk mencapai tujuan yang diharapkan.Adapun pendapat para ahli mengenai pengertian kinerja,sebagai berikut :Kinerja berasal dari kata job performance atau actual performance yang berarti prestasi kerja atau prestasi sesungguhnya yang dicapai oleh seseorang.Pengertian kinerja (prestasi kerja) adalah hasil kerja secara kualitas dan kuantitas yang dicapai oleh seorang pegawai dalam melaksanakan fungsinya sesuai dengan tanggung jawab yang diberikan kepadanya.

Performance atau kinerja merupakan hasil atau keluaran dari suatu proses (Nurlaila, 2010:71). Menurut pendekatan perilaku dalam manajemen, kinerja adalah kuantitas atau kualitas sesuatu yang dihasilkan atau jasa yang diberikan oleh seseorang yang melakukan pekerjaan (Luthans, 2006:165). Djamaluddin $\quad(2008: 87) \quad$ kinerja (performance) adalah kadar keberhasilan pegawai baik secara individu maupun bersama-sama dalam kelompok dan organisasi menjalankan kegiatan-kegiatan dengan sifat-sifat tertentu dalam menciptakan produk dan jasa-jasa untuk mencapai tujuan organisasi.

Mathis dan Jackson (2006:65) menyatakan bahwa kinerja pada dasarnya adalah apa yang dilakukan atau tidak dilakukan pegawai. Manajemen kinerja adalah keseluruhan kegiatan yang dilakukan untuk meningkatkan kinerja perusahaan atau organisasi, termasuk kinerja masingmasing individu dan kelompok kerja di perusahaan tersebut.

Copper dalam Samsudin ( 2006 : 159) mengungkapkan kinerja adalah tingkat pelaksanaan tugasyang dapat dicapai seseorang,unit,atau divisi dengan menggunakan kemampuan yang ada dan batasan-batasan yang telah ditetapkan untuk mencapai tujuan organisasi atau perusahaan. Sedarmiyati ( 2009: 50 ) mengungkapkan kinerja juga berarti prestasi kerja,pelaksanaan kerja, pencapaian kerja dan hasil / unjuk.

Bernandin \& Russell Mengungkapkan kinerja yang dihasilkan

P.ISSN: 1410-7988 E.ISSN: 2614-123X 
dari fungsi suatu pekerjaan tertentu atau kegiatan selama suatu periode tertentu.

August W. Smith dan Sedarmayanti menyatakan bahwa kinerja merupakan hasil atau keluaran dari suatu proses.Masih di dalam sutrisno (2009 : 164 ), pada umumnya kinerja diberi batasan sebagai kesuksesan seseorang didalam melaksanakan suatu pekerjaan.

\section{Faktor-faktor yang Mempengaruhi Kinerja}

a. Efektifitas dan efisiensi. Bila suatu tujuan tertentu akhirnya bisa dicapai, kita boleh mengatakan bahwa kegiatan tersebut efektif tetapi apabila akibatakibat yang tidak dicari kegiatan menilai yang penting dari hasil yang dicapai sehingga mengakibatkan kepuasan walaupun efektif dinamakan tidak efesien.Sebaliknya, bila akibat yang dicari-cari tidak penting atau remeh maka kegiatan tersebut efesien (Prawirosentono, 2009:27).

b. Otoritas (wewenang). Otoritas menurut adalah sifat dari suatu komunikasi atau perintah dalam suatu organisasi formal yang dimiliki seorang anggota organisasi kepada anggota yang lain untuk melakukan suatu kegiatan kerja sesuai dengan kontribusinya (Prawirosentono, 2009 :27). Perintah tersebut mengatakan apa yang boleh dilakukan dan yang tidak boleh dalam organisasi tersebut.

c. Disiplin. Disiplin adalah taat kepda hukum dan peraturan yang berlaku (Prawirosentono, 2009 :27).Jadi, disiplin karyawan adalah kegiatan karyawan yang bersangkutan dalam menghormati perjanjian kerja dengan organisasi dimana dia bekerja.

d. Inisiatif. Inisiatif yaitu berkaitan dengan daya pikir dan kreatifitas dalam membentuk ide untuk merencanakan sesuatu yang berkaitan dengan tujuan organisasi.

\section{Karakteristik Kinerja Pegawai}

Karakteristik orang yang mempunyai kinerja tinggi adalah sebagai berikut (Mangkunegara, 2006:68):

Eko dan Bisnis (Riau Economics and Business Reviewe) Volume 10, Nomor 3, 27 September 2019
1. Memiliki tanggung jawab pribadi yang tinggi.

2. Berani mengambil dan menanggung resiko yang dihadapi.

3. Memiliki tujuan yang realistis.

4. Memiliki rencana kerja yang menyeluruh dan berjuang untuk merealisasi tujuannya.

5. Memanfaatkan umpan balik (feed back) yang konkrit dalam seluruh kegiatan kerja yang dilakukannya.

6. Mencari kesempatan untuk merealisasikan rencana yang telah diprogramkan.

\section{Indikator Kinerja Pegawai}

Indikator untuk mengukur kinerja karyawan secara individu ada enam indikator, yaitu (Robbins, 2006:260):

1. Kualitas. Kualitas kerja diukur dari persepsi karyawan terhadap kualitas pekerjaan yang dihasilkan serta kesempurnaan tugas terhadap keterampilan dan kemampuan karyawan.

2. Kuantitas. Merupakan jumlah yang dihasilkan dinyatakan dalam istilah seperti jumlah unit, jumlahsiklus aktivitas yang diselesaikan.

3. Ketepatan waktu. Merupakan tingkat aktivitas diselesaikan pada awal waktu yang dinyatakan, dilihat dari sudut koordinasi dengan hasil output serta memaksimalkan waktu yang tersedia untuk aktivitas lain.

4. Efektivitas. Merupakan tingkat penggunaan sumber daya organisasi (tenaga, uang, teknologi, bahan baku) dimaksimalkan dengan maksud menaikkan hasil dari setiap unit dalam penggunaan sumber daya.

5. Kemandirian. Merupakan tingkat seorang karyawan yang nantinya akan dapat menjalankan fungsi kerjanya Komitmen kerja. Merupakan suatu tingkat dimana karyawan mempunyai komitmen kerja dengan instansi dan tanggungjawab karyawan terhadap kantor. 
6. Kedisiplinan. Disiplin merupakan sikap mental yang tecermin dalam perbuatan tingkah laku perorangan, kelompok atau masyarakat berupa kepatuhan atau ketaatan terhadap peraturan, ketentuan, etika, norma dan kaidah yang berlaku. Disiplin kerja adalah sikap kejiwaan seseorang atau kelompok yang senantiasa berkehendak untuk mengikuti atau mematuhi segala peraturan yang telah ditentukan. Kedisiplinan dapat dilakukan dengan latihan antara lain dengan bekerja menghargai waktu dan biaya akan memberikan pengaruh yang positif terhadap produktivitas kerja pegawai.

Pengertian Disiplin Menurut Para AhliPara Ahli memiliki pendapat masingmasing berikut ini beberapa pengertian disiplin menurut para ahli, yaitu:

Menurut James Drever dari sisi psikologis, disiplin adalah kemampuan mengendalikan perilaku yang berasal dari dalam diri seseorang sesuai dengan hal-hal yang telah di atur dari luar atau norma yang sudah ada. Dengan kata lain, disiplin dari segi psikologis merupakan perilaku seseorang yang muncul dan mampu menyesuaikan diri dengan aturan yang telah ditetapkan.

Menurut Pratt Fairshild dari sisi sosiologi, disiplin terdiri dari dua bagian, yaitu disiplin dari dalam diri dan juga disiplin sosial. Keduanya saling berhubungan satu sama lain, sehingga seseorang yang mempunyai sikap disiplin merupakan orangorang yang dapat mengarahkan perilaku dan perbuatannya berdasarkan patokan atau batasan tingkah laku tertentu yang diterima dalam kelompok atau lingkup sosial masingmasing. Pengaturan tingkah laku tersebut bisa diperoleh melalui jalur pendidikan dan pembelajaran.

Menurut John Macquarrie dari segi etika, disiplin adalah suatu kemauan dan perbuatan seseorang dalam mematuhi seluruh peraturan yang telah terangkai dengan tujuan tertentu.
Dari pengertian diatas dapat kita simpulkan bahwa disiplin mengacu pada pola tingkah laku dengan ciri-ciri sebagai berikut:

1) Adanya hasrat yang kuat untuk melaksanakan sepenuhnya apa yang sudah menjadi norma, etik, dan kaidah yang berlaku dalam masyarakat.

2) Adanya prilaku yang dikendalikan.

3) Adanya ketaatan (obedience)

Dari ciri-ciri pola tingkah laku pribadi disiplin, jelaslah bahwa disiplin membutuhkan pengorbanan, baik itu perasaan, waktu, kenikmatan dan lainlain.Disiplin bukanlah tujuan, melainkan sarana yang ikut memainkan peranan dalam pencapaian tujuan. Manusia sukses adalah manusia yang mampu mengatur, mengendalikan diri yang menyangkut pengaturan cara hidup dan mengatur cara kerja. Maka erat hubungannya antara manusia sukses dengan pribadi disiplin.Mengingat eratnya hubungan disiplin dengan produktivitas kerja maka disiplin mempunyai peran sentral dalam membentuk pola kerja dan etos kerja produktif.

Dari pengertian diatas dapat disimpulkan. Kedisiplinan pegawai adalah sikap penuh kerelaan dalam mematuhi semua aturan dan norma yang ada dalam menjalankan tugasnya sebagai bentuk tanggung jawabnyaterhadap pekerjaannya

1) Disiplin dalammenggunakan waktu.

2) Disiplin diri pribadi

3) Disiplin Sosial

4) Disiplin Nasional menacakup :

Disiplin nasional pada hakekatnya

(a) Terbitnya kesadaran masyarakat dan aparat penyelenggaraan terhadap artipentingnya disiplin negara.

(b) Tertibnya ketaatan bangsa kepada aturanhokum

(c) Terbentuk sistem perilaku demokrasi Konstitusi yang efektif dan efisien

Faktor yang mempengaruhi disiplin nasional: 
(a) Menerima pancasila sebagai satusatunya asas dalam berbangsa, bermasyarakat dan bernegara.

(b) Kita telah memiliki berbagai peraturan yang kita yakini kebenarannya

(c) Kita telah memahami, menghayati dan mengamalkan Pancasila

(d) Partisipasi masyarakat terhadap pembangunan.

\section{Indikator-Indikator Kedisiplinan}
a. Tujuan dan Kemampuan
b. Teladan Pimpinan
c. Balas jasa
d. Keadilan
e. Sanksi Hukuman
f. Ketegasan
g. Hubungan Kemanusiaan

\section{METODE}

\section{Lokasi Penelitian}

Adapun lokasi penelitian yang dijadikan objek penelitian ini adalah Instansi Dinas Perpustakaan kabupaten Indragiri hulu. Penelitian ini dilakukan selama kurang 6 bulan.

\section{Jenis Dan Sumber Data}

Dalam penelitian ini penulis bermaksud menggunakan data-data sebagai berikut :

1. Primer yaitu data yang diperoleh langsung dari lapangan yang berasal dari organisasi langsung.

2. Sumber data sekunder yaitu data yang berkaitan dengan dasar teoritis yang diperoleh dari studi pustaka maupun data yang diperoleh langsung dari Instansi,meliputi sejarah singkat Instansi,struktur organisasi Instansi,deskripsi pekerjaan serta bahanbahan lain yang diperlukan dalam pembahasan masalah.

\section{Populasi Dan Sampel}

Adapun populasi yang penulis jadikan dalam objek penelitian ini adalah seluruh pegawai pada Dinas Perpustakaan Kabupaten Indragiri Hulu sebanyak 85 orang. Dalam hal ini penulis menggunakan

Eko dan Bisnis (Riau Economics and Business Reviewe) Volume 10, Nomor 3, 27 September 2019 metode sensus yaitu tekhnik penentuan sampel bila semua anggota populasi digunakan sebagai sampel.

\section{Teknik Pengumpulan Data}

Dalam melakukan pengumpulan data, penulis menggunakan metode sebagai berikut :

1. Interview

2. Questioner

\section{Analisis Data}

Disamping menggunakan metode deskriptif, penulis juga menggunakan analisis data kualitatif,yaitu data yang berbentuk kalimat,kata atau gambar.Data kuntitatif, yaitu data yang berbentuk angka atau data kualitatif yang diangkakan (scoring). Selain ini metode yang menggunakan peralatan statistic yaitu analisis regresi linear berganda.

\section{Analisis Regresi Linear Berganda}

Analisis Regresi ini digunakan dengan melibatkan dua atau lebih variabel bebas antara variabel independen ( $\mathrm{Y}$ ) dan dependen $\left(\begin{array}{lll}X_{1} & \text { dan } & X_{2}\end{array}\right)$. Persamaan regresinya adalah sebagai berikut :

$$
\mathbf{Y}=\mathbf{a}+\mathbf{b}_{1} \mathbf{X}_{1}+\mathbf{b}_{2} \mathbf{X}_{2}
$$

\section{Koefisien Korelasi Berganda ( $r$ )}

Tujuan metode ini adalah analisis yang digunakan untuk membahas kuatnya hubungan antara variabel-variabel yang diteliti angka yang menunjukan hubungan antara variabel-variabel diberi notasi " "

$$
R=\frac{\sum X_{1} Y+b_{2 \sum X_{2} Y}}{\sum Y^{2}}
$$

\section{Pengujian Data}

\section{Uji Validitas Instrumen}

Validitas adalah suatu ukuran yang menunjukan tingkat-tingkat kevalidan atau kesahihan suatu instrumen. (Arikunto, $2013: 211$ )

Dalam pengujian validitas digunakan rumus korelasi product moment oleh Pearson sebagai berikut :

$$
\begin{aligned}
& \mathrm{r}_{\mathrm{xy}}=\frac{\mathrm{N} \cdot \sum \mathrm{XY}-\left(\sum \mathrm{X}\right)\left(\sum \mathrm{Y}\right)}{\sqrt{\left\{\sum \mathrm{X}^{2}-\left(\sum \mathrm{X}^{2}\right)\right\}\left\{\mathrm{N} \cdot \sum \mathrm{Y}^{2}-\left(\sum \mathrm{Y}^{2}\right)\right\}}} \\
& \text { P.ISSN: } 1410-7988 \quad \text { E.ISSN: } 2614-123 \mathrm{X}
\end{aligned}
$$


Hasil perhitungan $\quad r_{x y}$ dikonsultasikan dengan harga $r$ kritik product moment dengan tarif signifikan 5\% jika harga $r_{\text {hitung }}>r_{\text {tabel }}$ maka dikatakan item soal itu valid.

\section{Uji Reliabilitas Instrumen}

Reliabilitas instrumen menunjuk pada suatu pengeertian bahwa suatu instrumen dapat dipercaya untuk digunakan sebagai alat pengumpul data karena instrumen tersebut sudah baik. (Arikunto, 2013:221)

Untuk menguji realibilitas instrumen menggunakan rumus alpha, dapat digunakan uji realibilitas internal yang diperoleh dengan cara menganalisa data dan suatu hasil pengetesan dengan rumus sebagai berikut :

$$
r_{11}=\frac{(\mathrm{k})}{(k-1)} \frac{\left(1-\sum \sigma b^{2}\right)}{\sigma^{2} \mathrm{t}}
$$

Keterangan :

$r_{11}=$ reliabilitas instrumen

$\mathrm{k}=$ banyaknya butir soa

$\sum \sigma b^{2} \quad=$ jumlah varian butir

$\sigma^{2} \quad=$ varian total

Hasil uji reliabilitas angket penelitian selanjutnya dikonsultasikan dengan harga $r$ product moment pada tarif signifikan $5 \%$. jika harga $r_{11}>r_{\text {tabel }}$ maka instrumen dikatakan reliabel dan sebaliknya $r_{11}<r_{\text {tabel }}$ maka instrumen dikatakan tidak reliabel.

\section{Uji Normalitas Data}

Uji normalitas data dilihat dari grafik observed cum Probability. Apabila titik (data) masih berada diskitar garis maka disebut data normal.

\section{Uji Autokorelasi}

Untuk menilai variabel pengganggu (error term) tidak saling berhubungan dengan syarat indikatornya Du<dihitung $<4$ dU. Pengujian ini menggunakan Autkorelasi Durbin-Watson dimana :

$$
\begin{aligned}
& \text { DU }=\text { Durbin Upper } \\
& \text { DL }=\text { Durbin Lower }
\end{aligned}
$$

Eko dan Bisnis (Riau Economics and Business Reviewe) Volume 10, Nomor 3, 27 September 2019
Error term biasa disebut galat yaitu variabel Bebas lainnya (pengganggu) selain X1,X2.Y

\section{Uji Multikolinieritas}

Uji ini diterapkan untuk analisis regresi berganda ,yang terdiri dari dua atau lebih variabel bebas. Dimana akan diukur tingkat keeratan dan signifikan asosiasi (hubungan atau pengaruh), melalui perbandingan besaran koofesien korelasi (r). Untuk mengetahui apakah terjadi mesalah multikolinieritas antara variabel independen akan dilakukan dengan mengukur nilai VIF (Varian Inflation Faktor) dengan kaidah, apabila nilai VIF > 10, maka dapat dipastikan terjadi masalah multikolinieritas antara variabel independen (Yamin dan Kurniawan, 2009:91)

\section{Uji Heteroskedastisitas}

Untuk mengetahui bahwa variabel pengganggu (error term) sebaiknya kedastisitasnya dalam keadaan normal. Ketentuannya adalah signifikan korelasi spearman > 0.05 yang berarti hubungan antar X dan Y tidak signifikan atau heteros. Atau dapat juga diketahui dari gambar Scatterplot dimana titik (data) harus menyebar,apabila membentuk pola menumpuk berarti terjadi heteros.

\section{Uji F}

Menguji apakah variabel-variabel independen yang terdapat dalam model secara bersama-sama bisa menjelaskan atau tidak perubahan yang terjadi pada variabel bebas. Indikatornya adalah:

$$
F_{\text {hitung }}=\frac{\mathrm{r}^{2} /(\mathrm{k}-1)}{\left(1-\mathrm{r}^{2} /(\mathrm{N}-\mathrm{k})\right.}
$$

Keterangan :

$$
\begin{aligned}
& \mathrm{r}=\text { koofesien korelasi berganda } \\
& \mathrm{N}=\text { Banyaknya Data } \\
& \mathrm{k}=\text { jumlah variabel independen }
\end{aligned}
$$

\section{Uji Determinasi ( $R^{2}$ atau Adj $\left.R_{2}\right)$}

Yaitu pengujian yang bertujuan menilai berapa persen pengaruh dari variabel independen yang ada dalam model

$$
\text { P.ISSN: 1410-7988 E.ISSN: 2614-123X }
$$


berpengaruh terhadap variabel independen, sedangkan sisanya adalah pengaruh dari variabel lain. Formulasinya adalah (Iqbal Hasan, 2013:46)

Sedangkan untuk melihat kuat lemahnya pengaruh variabel yang digunakan analisis koefisien korelasi. Adapun formulasinya dari koefisien korelasi adalah: Besarnya nilai $\mathrm{R}$ adalah -1 s.d 1

1. Bila nilai $\mathrm{R}=1$ atau mendekati 1 , berarti pengaruh $\mathrm{X}$ dan $\mathrm{Y}$ adalah Sempurna dan Positif. Kenaikan dan penurunan $\mathrm{X}$ menyebabkan Kenaikan atau penurunan Y.

2. Bila nilai $\mathrm{R}=-1$ atau mendekati -1 berarti pengaruh $\mathrm{X}$ dan $\mathrm{Y}$ adalah Sempurna dan Negatif. Kenaikan dan penurunan $X$ menyebabkan Kenaikan atau penurunan Y.

3. Bila nilai $\mathrm{R}=0$ atau mendekati 0 berarti pengaruh $\mathrm{X}$ dan $\mathrm{Y}$ lemah sekali atau Korelasi antara X dan Y lemah.

\section{HASIL}

\section{Analisis Deskriptif Variabel Semangat Kerja}

Dari hasil penyebaran kuisioner, dapat dilihat bahwa Semangat Kerja pada Dinas Perpustakaan Kabupaten Indragiri Hulu diperoleh $X=3,88$ artinya Semangat Kerja pada Dinas Perpustakaan Kabupaten Indragiri Hulu tergolong Baik.

Analisis Deskriptif Variabel Kedisiplinan

Dari data kuisioner, dapat dilihat bahwa Kedisiplinan pada Dinas Perpustakaan Kabupaten Indragiri Hulu diperoleh X = 3,59 artinya Kedisiplinan pada Dinas Perpustakaan Kabupaten Indragiri Hulu tergolong Baik.

\section{Analisis Deskriptif Variabel Kinerja}

Dari data kuisioner, dapat dilihat bahwa Kinerja pada Dinas Perpustakaan Kabupaten Indragiri Hulu diperoleh X $=3,7 \overline{1}$ artinya Kinerja pada Dinas Perpustakaan Kabupaten Indragiri Hulu tergolong Baik.

\section{Pembahasan}

Untuk membuktikan dan menjelaskan tentang permasalahan yang dijadikan rumusan masalah ini sesuai dengan data yang Volume 10, Nomor 3, 27 September 2019 telah dihimpun maka peneliti akan melakukan uji dalam Penelitian ini menggunakan analisis regresi berganda dengan menggunakan program SPSS 20 for windows. Analisis ini digunakan untuk menganalisis pengaruh atau beberapa variabel independen terhadap variabel dependen.

\section{Uji Instrumen \\ Uji Validitas}

Tabel 3 Uji Validitas Variabel

\begin{tabular}{|c|c|c|c|c|}
\hline Variabel & Pernyataan & $\mathbf{r}$ hitung & $\mathbf{r}$ tabel & Keputusan \\
\hline Semangat Kerja & $\mathrm{K} 1$ & 0,588 & 0,344 & Valid \\
\cline { 2 - 5 } & $\mathrm{K} 2$ & 0,350 & 0,344 & Valid \\
\hline \multirow{4}{*}{ Kedisiplinan } & $\mathrm{K} 3$ & 0,512 & 0,344 & Valid \\
\hline & $\mathrm{K} 4$ & 0,565 & 0,344 & Valid \\
\hline \multirow{4}{*}{ Kinerja } & $\mathrm{K} 5$ & 0,373 & 0,344 & Valid \\
\cline { 2 - 5 } & $\mathrm{M} 2$ & 0,826 & 0,344 & Valid \\
\hline & $\mathrm{K} 3$ & 0,787 & 0,344 & Valid \\
\cline { 2 - 5 } & $\mathrm{K} 2$ & 0,544 & 0,344 & Valid \\
\cline { 2 - 5 } & $\mathrm{K} 3$ & 0,622 & 0,344 & Valid \\
\cline { 2 - 5 } & $\mathrm{K} 4$ & 0,483 & 0,344 & Valid \\
\cline { 2 - 5 } & $\mathrm{K} 5$ & 0,725 & 0,3444 & Valid \\
\hline
\end{tabular}

Sumber : Data Olahan Hasil Penelitian

Jika $r$ hitung $\geq r$ tabel, maka itemitem pernyataan dinyatakan valid. Nilai $r$ hitung dalam uji ini adalah Corrected Item Total Correlation. Sedangkan nilai $r$ tabel dapat dilihat pada tabel $\mathrm{r}$ dengan persamaan $\mathrm{N}-2=33-2=31=0,344$. Dan dari tabel diatas diperoleh nilai $r$ hitung seluruh pernyataan $>r$ tabel $(0,344)$. Artinya adalah alat ukur yang digunakan valid.

\section{Uji Reabilitas}

Tabel 4 Hasil Pengujian Reliabilitas

\begin{tabular}{|l|c|c|c|}
\hline \multicolumn{1}{|c|}{ Variabel } & $\begin{array}{c}\text { Cronbach's } \\
\text { Alpha }\end{array}$ & Nilai Kritis & Kesimpulan \\
\hline Kinerja & 0,639 & 0,6 & Reliabel \\
\hline Kedisiplinan & 0,890 & 0,6 & Reliabel \\
\hline Semangat Kerja Pegawai & 0,745 & 0,6 & Reliabel \\
\hline
\end{tabular}

Sumber : Data Olahan Hasil Penelitian

Jika nilai reliabilitas kurang dari 0,6 maka nilainya kurang baik. Artinya adalah bahwa alat ukur yang digunakan tidak reliable. Nilai reliabilitas dalam uji ini adalah pada kolom Reliabilitiy Statistics

$$
\text { P.ISSN: 1410-7988 E.ISSN: 2614-123X }
$$


(Cronbach's Alpha). Dari tabel diatas diperoleh nilai Cronbach's Alpha seluruh variabel > 0,6. Aritnya alat ukur yang digunakan reliabel/ dapat dipercaya.

\section{Uji Klasik \\ Uji Normalitas}

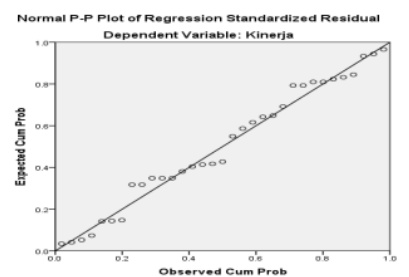

Dari gambar grafik uji normalitas di atas dapat dilihat bahwa data menyebar di sekitar garis diagonal dan mengikuti arah garis diagonal, maka variabel memenuhi asumsi normalitas.

\section{Uji Autokorelasi}

Tabel 5. Hasil Uji Autokorelasi Model Summary

\begin{tabular}{|l|r|}
\hline Model & Durbin-Watson \\
\hline 1 & \\
\hline
\end{tabular}

a. Predictors: (Constant), Semangat kerja, kedisipilinan

b. Dependent Variable: Kinerja

Nilai Durbin Watson > alpha (2,061 > 0,05), maka diantara variabel bebas dalam model persamaan regresi tidak terdapat autokorelasi.

\section{Uji Multikolinearitas}

Tabel 6. Hasil Uji Multikolinearitas

\begin{tabular}{|l|r|r|}
\multicolumn{1}{|c|}{ Coefficients $^{\mathrm{a}}$} & \multicolumn{2}{|c|}{ Collinearity Statistics } \\
\cline { 2 - 3 } & Tolerance & \multicolumn{1}{c|}{ VIF } \\
\hline (Constant) & & \\
Semangat kerja & .879 & $1.1 \mathrm{Br}$ \\
Kedisiplinan & .879 & 1.138 \\
\hline
\end{tabular}

Dari table di atas dapat dilihat jumlah Data tidak memiliki VIF lebih dari 10 maka dapat disimpulkan tidak terdapat multikolinieritas.

\section{Uji Heteroskedastisitas}

Uji heteroskedastisitas yaitu untuk mengetahui bahwa variabel pengganggu (error term) sebaiknya kedastisitasnya dalam keadaan normal. Ketentuannya adalah signifikan korelasi spearman $>0.05$ yang berarti hubungan antara $\mathrm{Y}$ dan $\mathrm{Y}$ tidak signifikan atau heteros. Atau dapat juga diketahui dari gambar Scatterplot di mana titik (data) harus menyebar, apabila membentuk pola menumpuk berarti terjadi Eko dan Bisnis (Riau Economics and Business Reviewe) Volume 10, Nomor 3, 27 September 2019 heteros. Sehingga kita dapat mengetahui uji Heteroskedastisitas berikut:

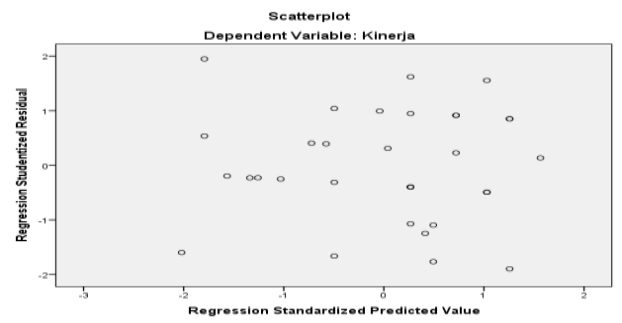

Dari gambar Scatterplot diatas terlihat titik-titik tidak membentuk pola tertentu dan menyebar secara acak diatas dan dibawah angka 0 pada sumbu Y. Dan berdasarkan uji korelasi Spearman's Rho diatas diperoleh nilai signifikansi variabel independen dengan Residual > 0,05. Dapat diartikan tidak terdapat heterokedastisitas dalam model regresi penelitian ini.

\section{Persamaan Regresi}

Berikut adalah hasil nilai estimasi koefisien regresi berganda yang dihasilkan:

Tabel 7 Koefisien Korelasi Berganda

\begin{tabular}{|c|c|c|c|c|c|c|}
\hline \multirow{3}{*}{ Model } & & \multicolumn{5}{|c|}{ Coefficients ${ }^{a}$} \\
\hline & & \multicolumn{2}{|c|}{ Unstandardized Coefficients } & \multirow{2}{*}{$\begin{array}{c}\begin{array}{c}\text { Standardized } \\
\text { Coefficients }\end{array} \\
\text { Beta }\end{array}$} & \multirow[t]{2}{*}{$t$} & \multirow[t]{2}{*}{ Sig. } \\
\hline & & $B$ & Stod. Error & & & \\
\hline \multirow{3}{*}{1} & (Constant) & 15.597 & 5.457 & & 2858 & .008 \\
\hline & Semangat kerja & .130 & .206 & .123 & .633 & .531 \\
\hline & Kedisiplinan & .039 & .239 & .031 & .163 & .872 \\
\hline
\end{tabular}

Sumber : Data diolah mengunakan SPSS 20 for windows.

Persamaan Regresinya sebagai berikut:

$$
\begin{aligned}
& Y=\alpha+\beta_{1} X_{1}+\beta_{2} X_{2} \\
& Y=15.597+0.130 X 1+0.039 X 2
\end{aligned}
$$

Keterangan:

$$
\begin{array}{ll}
\mathrm{Y} & =\text { Kinerja } \\
\alpha & =\text { Konstanta } \\
\beta_{1}, \beta_{2} & =\text { Koefisien Regresi } \\
\mathrm{X}_{1} & =\text { Semangat kerja } \\
\mathrm{X}_{2} & =\text { Kedisiplinan }
\end{array}
$$

Persamaan Regresi di atas dapat dijelaskan sebagai berikut:

a. Konstanta sebesar 15.597. artinya nilai konstanta ini menunjukkan bahwa apabila variabel Semangat kerja $\left(X_{1}\right)$ dan Kedisiplinan $\left(\mathrm{X}_{2}\right)$ nilainya adalah 0 , maka kinerja (Y) nilainya adalah 15.597.

b. Koefisien regresi variabel Semangat Kerja $\left(\mathrm{X}_{1}\right)$ sebesar 0.130. Artinya jika komunikasi naik sebesar satu satuan, 
sedangkan variable semangat kerja tetap maka kinerja naik sebesar 0.130 .

c. Koefisien regresi variabel Kedisiplinan $\left(\mathrm{X}_{2}\right)$ sebesar 0.039. artinya jika variabel Kedisiplinan nilainya tetap dan Kedisiplinan mengalami kenaikan satu satuan, maka kinerja (Y) naik sebesar 0.039 .

\section{Koefisien Korelasi dan Determinasi ( $R$ square)}

Koefisien determinasi atau R Square menunjukkan persentase seberapa besar pengaruh variabel bebas terhadap perubahan variabel terikat. Berikut adalah nilai RSquare yang diperoleh dari hasil analisis:

Tabel 8 Koefisien Determinasi ( $R$ square)

\begin{tabular}{|l|c|r|c|c|c|}
\hline Model & $R$ & $R$ Square & $\begin{array}{c}\text { Adjusted } R \\
\text { Square }\end{array}$ & $\begin{array}{c}\text { Std. Error of the } \\
\text { Estimate }\end{array}$ & Durbin-Watson \\
\hline 1 & $.915^{\circ}$ & .813 & .052 & 1.51929 & 2.094 \\
\hline a. Predictors: (Constant). Semangat kerja dan kedisiplinan \\
\hline b. Dependent Variable: Kineria
\end{tabular}

Berdasarkan tabel analisis di atas diperoleh angka $\mathrm{R}$ yang disebut juga dengan koefisien Korelasi antara Semangat Kerja dan Kedisiplinan terhadap kinerja adalah sebesar 0.915 berarti mendekati 1, maka disini dapat dikatakan bahwa semangat kerja dan kedisiplinan terhadap kinerja terdapat hubungan yang sangat kuat atau positif.

Sedangkan berdasarkan tabel analisis di atas diperoleh angka $\mathrm{R}^{2}$ (R Square) atau disebut koefisien determinasi adalah sebesar 0.813 . artinya $81.3 \%$. menunjukkan persentase sumbangan variabel independen (semangat kerja dan kedisiplinan) terhadap variabel dependen (kinerja) Atau variasi variabel independen yang digunakan dalam model (semangat kerja dan kedisiplinan) mampu menjelaskan sebesar $81.3 \%$ dari variasi variabel dependen (kinerja). Sedangkan sisanya sebesar $18.7 \%$ dipengaruhi oleh variabel lain yang tidak diteliti dalam penelitian ini.
Pengujian Hipotesis dengan uji F

Tabel 9. Uji F Variabel Bebas dengan Variabel Terikat

\begin{tabular}{|c|c|c|c|c|c|c|}
\hline Model & & Sum of Squares & $\frac{\mathrm{NOVA}^{\mathrm{a}}}{\mathrm{df}}$ & Mean Square & & Sig. \\
\hline \multirow{3}{*}{1} & Regression & .935 & 2 & .467 & 11.202 & $.00017^{\circ}$ \\
\hline & Residual & 69.247 & 30 & 2.308 & & \\
\hline & Total & 70.182 & 32 & & & \\
\hline
\end{tabular}

menunjukan nilai $F_{\text {hitung }}$ sebesar 11.202 dengan nilai signifikansi sebesar 0.00017. Jadi $F_{\text {hitung }}>F_{\text {tabel }}(11.202>3.32)$ atau Sig $\mathrm{F}<5 \%(0.00017<0,05)$ Karena nilai signifikansi uji $\mathrm{F}$ lebih kecil dari tingkat signifikan 0,05 , dan $\mathrm{F}_{\text {hitung }}>\mathrm{F}_{\text {tabel }}$ maka Ho ditolak dan $\mathrm{Ha}$ diterima, sehingga dapat diartikan bahwa secara Simultan semangat kerja dan kedisiplinan berpengaruh signifikan terhadap kinerja.

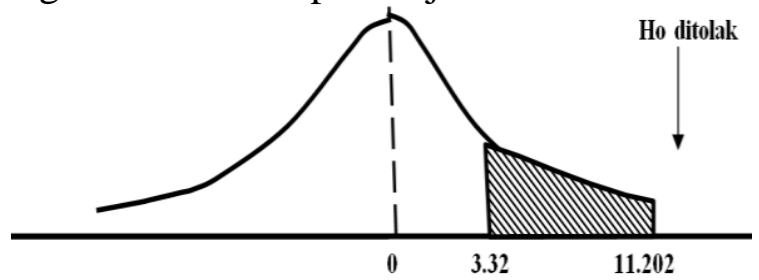

Hasil uji diatas $F_{\text {hitung }}>F_{\text {tabel }}(11.202$ < 3.32) jadi Ho ditolak dan Ha diterima. Maka dari hasil uji diatas disimpulkan bahwa hipotesis penelitian yang menduga terdapat pengaruh semangat kerja dan kedisiplinan terhadap kinerja pegawai tidak terbukti kebenarannya.

\section{SIMPULAN}

1. Diperoleh Persamaan Regresi Linier Bergandanya adalah. Konstanta sebesar 15.597 artinya nilai konstanta ini menunjukkan bahwa apabila variabel Semangat Kerja $\left(\mathrm{X}_{1}\right)$ dan Kedisiplinan $\left(\mathrm{X}_{2}\right)$ nilainya adalah 0 , maka kinerja (Y) nilainya adalah 15.597. Koefisien regresi variabel Semangat Kerja $\left(\mathrm{X}_{1}\right)$ sebesar 0.130. Artinya jika Kinerja naik sebesar satu satuan, sedangkan variable semangat kerja tetap maka kinerja naik sebesar 0.130 . Koefisien regresi variabel Kedisiplinan $\left(\mathrm{X}_{2}\right)$ sebesar 0.039 artinya jika variabel kedisiplinan nilainya tetap dan semangat kerja mengalami kenaikan 
satu satuan, maka kinerja (Y) naik sebesar 0.039 .

2. Hasil Uji Fsimultan menyatakan bahwa diperoleh hasil $F_{\text {hitung }}$ sebesar 11.202 dengan nilai signifikansi sebesar 0.00017. Jadi $F_{\text {hitung }}>F_{\text {tabel }}(11.202<$ 3.32) atau Sig F $<5 \%(0.00017>0,05)$ Karena nilai signifikansi uji $\mathrm{F}$ lebih kecil dari tingkat signifikan 0,05 , dan $F_{\text {hitung }}>$ $F_{\text {tabel }}$ maka Ho ditolak dan Ha diterima, sehingga dapat diartikan bahwa secara Simultan Semngat Kerja dan Kedisiplinan berpengaruh signifikan terhadap kinerja.

3. Diperoleh angka $\mathrm{R}$ sebesar 0.915 berarti mendekati 1, maka disini dapat dikatakan bahwa semangat kerja dan kedisiplinan terhadap kinerja terdapat hubungan yang sangat kuat atau positif. Sedangkan berdasarkan tabel analisis di atas diperoleh angka $\mathrm{R}^{2}$ ( $\mathrm{R}$ Square) atau disebut koefisien determinasi adalah sebesar 0.813. artinya 81.3\%. menunjukkan persentase sumbangan variabel independen (Semngat Kerja dan Kedisiplinan) terhadap variabel dependen (kinerja) Atau variasi variabel independen yang digunakan dalam model (Semngat Kerja dan Kedisiplinan) mampu menjelaskan sebesar $81.3 \%$ dari variasi variabel dependen (kinerja). Sedangkan sisanya sebesar $18.7 \%$ dipengaruhi oleh variabel lain yang tidak diteliti dalam penelitian ini.

\section{DAFTAR RUJUKAN}

Gilang Nugraha, 2013 , Pengaruh insentif financial dan insentif non financial terhadap semangat kerja dan semangat kerja pegawai

Husein, 2000, Hubungan antara disiplin kerja dengan prestasi kerja.Jakarta

Http : //www.pdffactory.com

Mardjan Dunggio, 2003 , Semangat dan disiplin kerja terhadap produktifitas kerja

Mathis,R.L \& J,H.jackson , 2006. Sumber daya manusia.jakarta. selemba empat

Mutiara bunda ulil albab, 2014, Pengaruh disiplin kerja pegawai.Bandung

Eko dan Bisnis (Riau Economics and Business Reviewe) Volume 10, Nomor 3, 27 September 2019
Moliadi irfan , 2013 , Dasar- dasar kepustakawan.makassar

Prabowo narmado, 2006, Pengaruh semangat kerja dan disiplin kerja terhadap kinerja karyawan.wonogiri

Sugiono , 2006, Metode penelitian kuntitatif dan kualitatif, ALFABETA. Bandung

Subagyo, P, 2007, Manajemen Kepegawaian, Ghalia Indonesia, Jakarta.

Tjahjono,Binawan nur,2006,Pengaruh semangat kerja kerja dan budaya organisasi terhadap kinerja pegawai.

Utami ayu bakti, 2015, Pemanfaatan layanan perpustakaan bagi kalangan remaja.Surabaya

Gibson, dkk. 2009.Organizational : Behavior, Strukture, Processes, The Mc Graw Hill Companies, Inc, New Yourk.

http://digilib.uinsby.ac.id/295/3/Bab\%2012 .pdf

https://www.kajianpustaka.com/2014/01/p engertian-indikator-faktormempengaruhi-kinerja.html? $\mathrm{m}=1$

Mangkuprawira, Sjafri. 2009. Bisnis, Manajemen dan Sumber Daya Manusia. IPB Press. Bogor.

Sedarmayanti. 2009. Sumber Daya Manusia dan Produktivitas Kerja. CV Mandar Maju. Bandung.

Sedarmayanti. 2009. Tata Kerja dan Produktivitas Kerja. CV Mandar Maju. Bandung.

Robbins, stepphen 2007, Manajemen, Edisi Kedelapan, Penerbit PT Indeks Jakarta.

P.ISSN: 1410-7988 E.ISSN: 2614-123X 